\title{
Spatial Pattern of Agriculture Productivity of Crops in Cauvery Delta Zone of Tamilnadu
}

\author{
C. Arul Kumar ${ }^{1}$ and G. Manimannan ${ }^{2}$ \\ ${ }^{1}$ Assistant Professor, Vivekanandha College of Arts and Sciences for Women, Tiruchengode, Namakkal, \\ Tamilnadu, INDIA. \\ ${ }^{2}$ Assistant Professor, Madras Christian College, Tambaram, Chennai, Tamilnadu, INDIA.
}

\begin{abstract}
Agriculture still forms the life line of our Indian economy and vital activity of a human being. Agriculture sector in India contributes nearly half of the national income, providing jobs to three fourth of the total population. In short agriculture plays a significant role in the economic development process of a country and agriculture continues to be the most predominant sector of the Tamilnadu economy. Agriculture productivity has been an important issue as the population continues to grow. But in the recent year's agriculture lands are converted to real estate business in major Indian cities, particularly Tamilnadu real estate business attained a boom to the core extent. In this context, the researcher has a keen interest to indentify the spatial pattern of agriculture productivity. The concept of agricultural productivity has been extensively used to explain the spatial organization and patterns of agriculture. Agriculture productivity has been measured by several scholars using different methods. This research paper attempts to identify spatial pattern of Cauvery Delta zone based on agriculture productivity index, the study area includes the districts of Thiruchirappalli, Ariyalur, Thanjavur, Nagapattinam, Thiruvarur and a part of Pudukkottai. The data was collected from secondary source of Department of Economics and Statistics, Tamilnadu during the year 2011-2012. Among various productivity index methods, the researcher chosen Enyedi's Method and this method applied to compute crop productivity index because of its accuracy. The productivity index values were calculated and differentiated the productivity regions as High Productivity Region (HPR), Moderate Productivity Region (MPR) and Low Productivity Region (LPR).
\end{abstract}

Keywords: Agriculture Productivity, Productivity Region, Crop Productivity Index, Cauvery Delta Zone, Enyedi's method

\section{Introduction}

Agriculture lands are mostly occupied by real estate business people and government in the major cities and corporation for industrial and urbanization purpose. Real estate people buy agriculture lands at a cheap rate and they get higher benefits. Farmers sell their cultivable land because rainfall level is lower for the past ten years and other reasons for delta zone formers, especially they depending on Cauvery water. Cauvery water issue between the two states of Tamilnadu and Karnataka also played a vital role. Without water they could not cultivate any crops. In this situation, the minimal land owners sold their properties to real estate people or otherwise they themselves converted their agriculture land into plots. The maximum agriculture land owners still retain their properties, because they have bore well water for irrigation. Now the cultivable land area has a decreasing trend, The IT employees or higher salaried people buy more lands and flats just for investment purpose even though they possess own house or own plots,. As they offer more prices, farmers agree to sell without proper knowledge and guidance. In this context, the researcher has keen interest to conduct a study on spatial pattern of agriculture productivity in Cauvery Delta Zone. Agriculture still forms the life line of our Indian economy and vital activity of a human being. Agriculture sector in India contribute nearly half of the national income, provides jobs to $3 / 4^{\text {th }}$ of the total population and supplies lot of goods and raw materials required by the non-agriculture sectors. In short agriculture plays a significant role in the economic development process of a country. Agriculture continues to be the most predominant sector of the Tamilnadu economy, over seventy percent of the population engaged in agriculture and allied activities for their livelihood. Tamil Nadu has about seven percent of the Nation's population. The annual average rainfall of Tamil Nadu is only $930 \mathrm{~mm}$. The total geographical area of Tamilnadu is 130 lakh hectares, which is 4 percent of the nation's geographical area, around 48.92 lakh hectares is the net cultivated land area.

Many researchers state that, agricultural productivity is a multidimensional concept, which includes technological advancement, effective management of available resources and organizational setup for the agricultural production. These factors in turn affect the relative production in any region. The term productivity is regarded as the measurement of production and inputs required for the production of that output is known as agricultural productivity (Sunil Ogale and Virendra Nagarle, 2014). The agriculture productivity is a quantitative term which provides an estimate of power of agriculture to produce crops. Agricultural productivity 
has been defined by several scholars with reference to their own view and discipline. Agriculture productivity may be defined as the 'ratio of index of local agricultural output to the index of total input used in farm production (Shafi, 1984). Singh and Dhillon (2000) suggested that the 'yield per unit should be considered to indicate agriculture productivity.' Jasbir singh (1972) considered 'productivity is the degree of which the economic, cultural, technical and organizational variables are able to exploit the biotic resources of the areas for agricultural production. Bhatia (1967) defined agricultural efficiency as 'the aggregate performance of various crops in regard to their output per acre'.

\section{Review Of Literature}

In the field of agriculture productivity, various scholars have used different techniques to measure the agriculture productivity and spatial patterns at national and International level. Stamp (1958) applied Kendall's ranking coefficient technique on an international level in order to determine agricultural efficiency of a number of countries as well as some major crops. Shafi (1960) applied the technique of ranking coefficient of Kendall for measuring the agricultural efficiency in the state of Uttar Pradesh, taking eight crops grown in forty eight districts in the state. Rahman (2003) attempted to examine variations in crop productivity in North Bihar Plain considering 17 major crops grown in the districts of the region during the period of 1995-2000. Jahan mohan et al., (2005) in his study found that area and production of cereal crops registered a negative trend in the entire agro climatic zone with the exception of western and southern zone that showed positive trend in the area of cotton.

Dharmasiri (2009) has applied average productivity index to measure the agriculture productivity in Srilanka. Kalaivani et al. (2010) used Compound Growth Rate to measure the growth actions of area, production and yield for selected crops in Tamilnadu. In his study maize was recorded a positive trend in Tamilnadu. Sakthi Mandal (2012) studied the spatial variation of agriculture productivity using Z - score model and categorized the blocks as Very High, High, Medium and Low of agricultural productivity in south 24 PGS, Districts of West Bengal. Muthumurugan et al. (2012) suggested composite index analysis to study the agriculture development of Tamilnadu. He classified the districts based on the index value as highly developed, medium developed and low developed. Pajer Mansaram Pandit (2012), his study revealed that road, railway, agricultural labour, bank, good climate and modern technology are the important factors in the agriculture development of Nasik District. A. S. Rotaru et al. (2012) demonstrated factor analysis in agriculture by downsizing the data with various crops in the regions of Romania. Shafiquallah (2013) applied the technique Z-score model to study regional disparities and agricultural development in Uttar Pradesh. In the recent study C. Arul Kumar and G. Manimanan (2014) have applied multivariate statistical techniques for the purposes of data reduction and classification. The results falls under three categories of classes, namely high, moderate and low yield of agriculture productivity for 14 crops in north western zone of Tamilnadu.

\section{Study Region}

Tamilnadu has been classified into seven Agro Climatic Zones based on soil characteristics, rainfall distribution, irrigation pattern, cropping pattern and other social characteristics. For the present study the researcher has chosen Cauvery Delta Zone of Tamilnadu. Cauvery Delta Zone lies in the eastern part of Tamil Nadu between 10.00-11.30, North latitude and between $78.15-79.45$ longitudes. It is bounded by the Bay of Bengal on the East and the Palk straight on the South, Trichy district on the west, Perambalur, Ariyalur districts on the North West, Cuddalore district on the North and Puddukkottai district on the South West. This zone covers Thanjavur, Nagapattinam, Tiruvarur, Tiruchirapalli, Ariyalur and Pudukkottai districts. This zone lies at the bottom of the Cauvery river basin. Total area of the zone is $24,943 \mathrm{sq} . \mathrm{km}$. in which 60.2 per cent of the area i.e., 15, 00,680 hectares are under cultivation and 50.1 per cent of total area of cultivation This zone receives an annual normal rainfall of $956.3 \mathrm{~mm}$. It covers the rivers of Cauvery, Vennaru, Kudamuruti, Paminiar, Arasalar and Kollidam. The major dams utilized by this zone are Mettur and Bhavanisagar. Canal irrigation, well irrigation and lake irrigation are under practice. Thanjavur district, which is known as "Rice Bowl" of Tamilnadu, comes under this zone. The main objective of this paper is to identify the spatial pattern of agricultural productivity of crops in the Cauvery delta zone of Tamilnadu.

\section{Database And Methodology}

The present study attempts to identify agriculture productivity index in the regions of Cauvery delta zone of Tamilnadu for the year 2011-2012. In this study, 15 major crops grown in this zone were selected carefully. These crops were grouped into four categories (a) Cereal crops to include paddy, cholam, cumbu, ragi, and maize (b) pulses include bengalgram, redgram, blackgram, greengram and horsegram (c) oil seeds include groundnut, gingelly and coconut (d) cash crops include sugarcane and tapioca. The present work is based on secondary sources of data. The required data for analysis is collected from Department of Economics and Statistics, Chennai and Statistical Hand book of Tamil Nadu. After taken a review of several methods, Enyedi's 
method was chosen to compute crop productivity index for Cauvery delta zone for the year 2011-2012 because of its accuracy.

$$
\text { Productivity Index }=\frac{Y}{Y_{n}} \div \frac{T}{T_{n}} * 100
$$

Where $Y$ - Production of the selected crops in an unit area i.e., district,

$Y_{n}$ - Total Production of the selected crops at the entire zone,

$T$ - Area under selected crops in unit area,

$T_{n}$ - Total cropped area in the entire zone.

Using the above formula the productivity index were calculated for the districts of Cauvery delta zone for the year 2011-2012 and demarcated the productivity regions as high, moderate and low productivity regions.

In order to classify the productivity regions of Cauvery delta zone on the basis of productivity indices, the statistical method quartiles was applied. Quartiles are three points that divide a range of data set into four equal parts. The first quartile is the number below which lies the 25 percent of the bottom data. The second quartile divides the range in the middle and has 50 percent of the data below it. The third quartile has 75 percent of the data below it and the top 25 percent of the data above it. In this research paper for the classification purpose, quartiles were also calculated for agriculture productivity index values to classify the productivity in districts of delta zone region. The algorithm for classification procedure is as follows

Step 1: The index value which lies below in the first quartile was named as Low Productivity Regions (LPR).

Step 2: The districts which have the index value lies between first and third quartiles is marked as Moderate Productivity Regions (MRP).

Step 3: The districts index values which lies above the third quartile is named as High Productivity Regions (HPR). These results of index values are shown in the Table and in the spatial pattern Map in the following section.

\section{Results And Discussions}

In this research paper an attempt is made to identify the agriculture productivity regions of Cauvery delta zone of Tamil Nadu for the year 2011-2012. Initially Enyedi's method was applied and calculated the agriculture crop productivity index values and these values are used to classify the regions as HPR, MPR and LPR. The classification of regions based on productivity indices are discussed below.

\subsection{Productivity Regions Based On Cereal Crops}

Cereals are the important crop grown in this zone covers an area of 772 thousand hectares $(59.8$ percent) of the total cropped area. Rice itself cover 55.7 percent of total cultivated area of this zone. HPR observed in the district of Ariyalur, because high productivity indices are due to heavy rainfall recorded in the district. MPR observed in Trichy, Thanjavur, Thriuvarur and Pudukottai districts. Nagapattianm marked with LPR. Non release of water in canals and delayed on set of monsoon are the factors which affected the productivity. The results of productivity index for cereals crops shown in Table1 and Fig. 2.

Table 1. Districts, Area (in Hectare), Production (in Tonnes) and Productivity index of Cereal Crops

\begin{tabular}{|c|c|c|c|c|}
\hline \multicolumn{4}{|c|}{ Cereal Crops } & Agriculture field of Cereals (Source: TNAU) \\
\hline Districts & $\begin{array}{c}\text { Area } \\
\text { (in hectare) }\end{array}$ & $\begin{array}{l}\text { Production } \\
\text { (In Tonnes) }\end{array}$ & $\begin{array}{c}\text { Index } \\
\text { of Productivity }\end{array}$ & \\
\hline Ariyalur & 038519 & 164211 & 110.26 & \\
\hline Thanjavur & 182159 & 730317 & 103.70 & \\
\hline Thiruvarur & 186310 & 790017 & 109.68 & \\
\hline Nagapattinam & 170059 & 577123 & 87.780 & \\
\hline Pudukottai & 098284 & 371192 & 97.68 & \\
\hline Trichy & 096242 & 350112 & 94.095 & \multirow{2}{*}{ 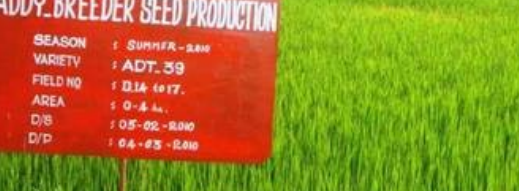 } \\
\hline Total & 771573 & 2982972 & & \\
\hline
\end{tabular}




\section{2 Productivity Regions Based On Pulses}

Wikipedia states that India is the world's largest producer and largest consumer of pulses. Pakistan, Canada, Burma, Australia and the United States, are significant exporters and are India's most significant suppliers. Pulses are useful for both humans and other animals. In this study, the researcher covered the following pulses Bengalgram, Redgram, Blackgram, Greengram and Horsegram. These are the major pulses grown in the region. They occupied 207 thousand hectares (16.05 percent) of the total cropped area. On the basis of calculated productivity index HPR has been observed in Ariyalur district. Four districts Pudukottai, Thanjavur, Thriuvarur and Trichy lie in MPR and the remaining district of Nagapattinam shows LPR which are shown in Table 2 and Fig. 3.

Table 2. Districts, Area (in Hectare), Production (in Tonnes) and Productivity index of Cereal Crops

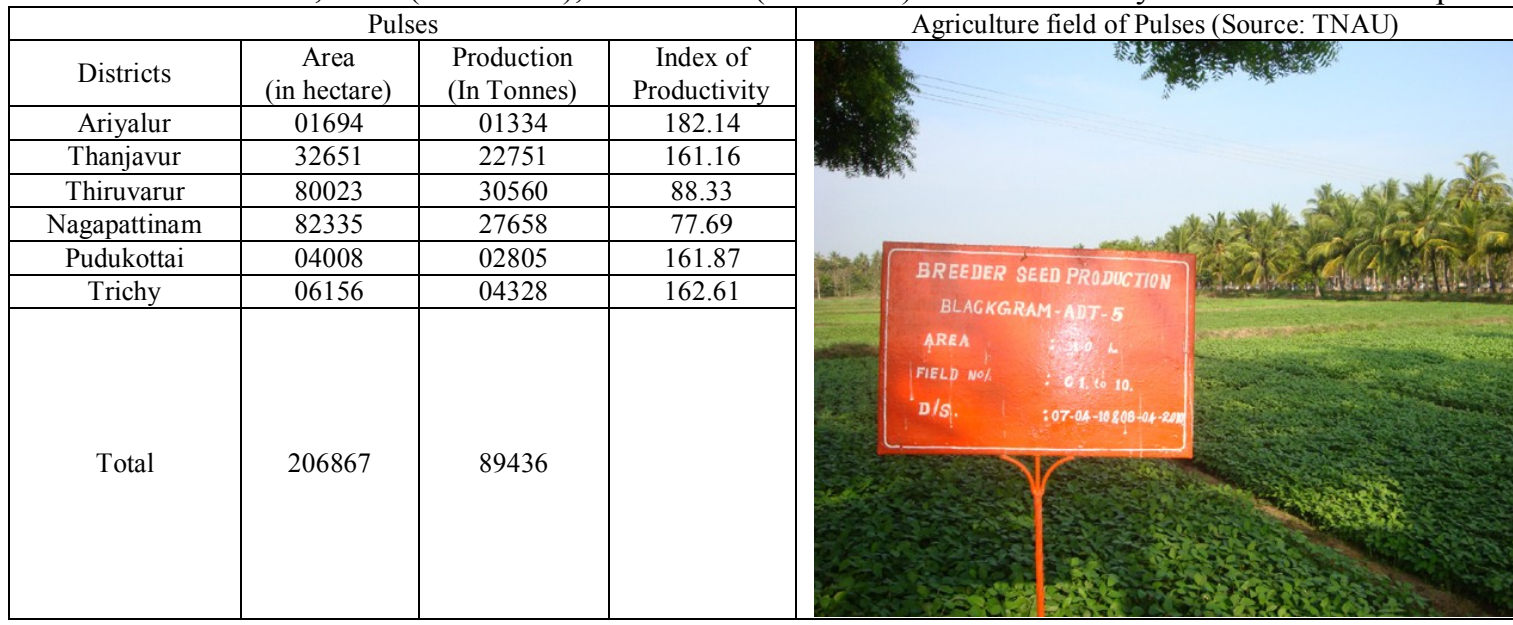

\subsection{Productivity Regions Based On Oilseeds}

Groundnut, Gingelly and Coconut are the main oil seeds grown in this zone in Rabi (winter) season with limited irrigation. High productivity region (HPR) of oil seeds has observed in Ariyalur. The districts having Moderate Productivity Region (MPR) were namely Nagapattinam, Pudukottai, Thiruvarur and Trichy, while Thanjavur marked with Low Productivity Region (LPR) which is shown in Table 3 and Fig. 4.

Table 3. Districts, Area (in Hectare), Production (in Tonnes) and Productivity index of Oil Seeds

\begin{tabular}{|c|c|c|c|c|c|c|}
\hline \multicolumn{9}{|c|}{ Cereal Crops } & \multicolumn{2}{c|}{ Agriculture field of Oilseeds (Source: TNAU) } \\
\hline Districts & $\begin{array}{c}\text { Area } \\
\text { (in hectare) }\end{array}$ & $\begin{array}{c}\text { Production } \\
\text { (In Tonnes) }\end{array}$ & $\begin{array}{c}\text { Index } \\
\text { of } \\
\text { Productivity }\end{array}$ &
\end{tabular}

\subsection{Productivity Regions Based On Cash Crops}

Cultivation of cash crops plays an important role in agricultural economy. Cash crops covered nearly 45 thousand hectares and accounted for 3.5 percent of total cropped area. From Table 4 and Fig. 5, it is observed that Pudukottai district attained HPR. The four districts Thanjavur, Thiruvarur, Trichy and Ariyalur have recorded with MPR. Once again Nagapattinam marked with LPR. 
Table 4. Districts, Area (in Hectare), Production (in Tonnes) and Productivity index of Cash Crops

\begin{tabular}{|c|c|c|c|c|}
\hline \multicolumn{4}{|c|}{ Pulses } & Agriculture field of cash crops (Source: TNAU) \\
\hline Districts & $\begin{array}{c}\text { Area } \\
\text { (in hectare) }\end{array}$ & $\begin{array}{l}\text { Production } \\
\text { (In Tonnes) }\end{array}$ & $\begin{array}{c}\text { Index of } \\
\text { Productivit } \\
y\end{array}$ & \\
\hline Ariyalur & 8252 & 890541 & 105.47 & \\
\hline Thanjavur & 11037 & 1194068 & 105.73 & \\
\hline Thiruvarur & 755 & 66375 & 85.92 & \\
\hline Nagapattinam & 3738.00 & 273593 & 71.53 & \\
\hline Pudukottai & 9442 & 1218368 & 126.11 & \\
\hline Trichy & 11247 & 907192 & 78.83 & 98 \\
\hline Total & 44471 & 4550137 & & \\
\hline
\end{tabular}

In Table 5 and Figure 1, consolidated results of the various crops productivity index for various districts in the delta zone of Tamilnadu are shown. Table 6, 7,8 and 9 shows the result of spatial pattern in various districts of delta zone.

Table 5. and Figure 1. Consolidated Productivity index of various crops

\begin{tabular}{|c|c|c|c|c|c|c|}
\hline S.No & Districts & $\begin{array}{l}\text { Cereal } \\
\text { Crops }\end{array}$ & Pulses & $\begin{array}{c}\text { Oil } \\
\text { seeds }\end{array}$ & $\begin{array}{l}\text { Cash } \\
\text { crops }\end{array}$ & Figure 1. Consolidated Productivity index for various crops \\
\hline 1 & Ariyalur & 110.27 & 182.15 & 239.9 & 105.47 & 300 \\
\hline 2 & Nagapattinam & 87.78 & 77.699 & 93.251 & 71.535 & 250 \\
\hline 3 & Pudukottai & 97.689 & 161.88 & 93.399 & 126.12 & 250 \\
\hline 4 & Thanjavur & 103.7 & 161.17 & 49.69 & 105.74 & \\
\hline 5 & Thiruvarur & 109.68 & 88.332 & 159.11 & 85.923 & - Cereal Crops \\
\hline 6 & Trichy & 94.096 & 162.62 & 96.34 & 78.834 & - Cash crops \\
\hline
\end{tabular}

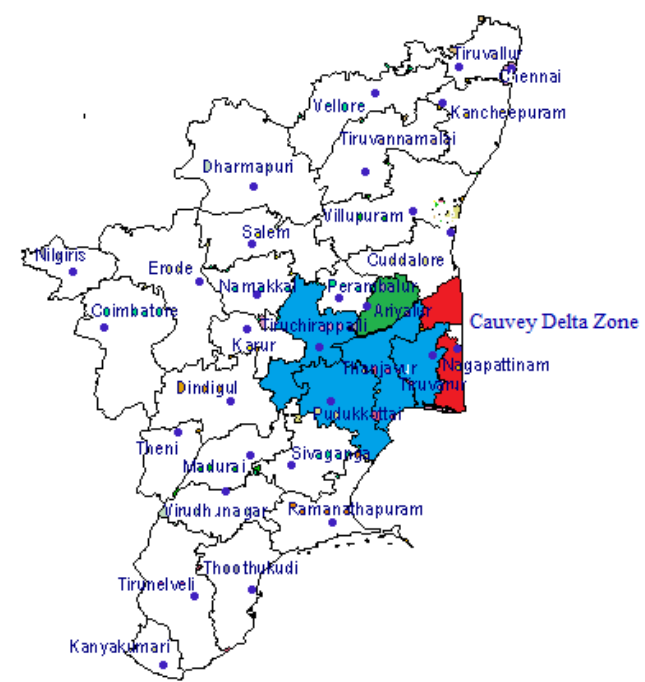

Figure 2. Spatial Pattern of Cereals

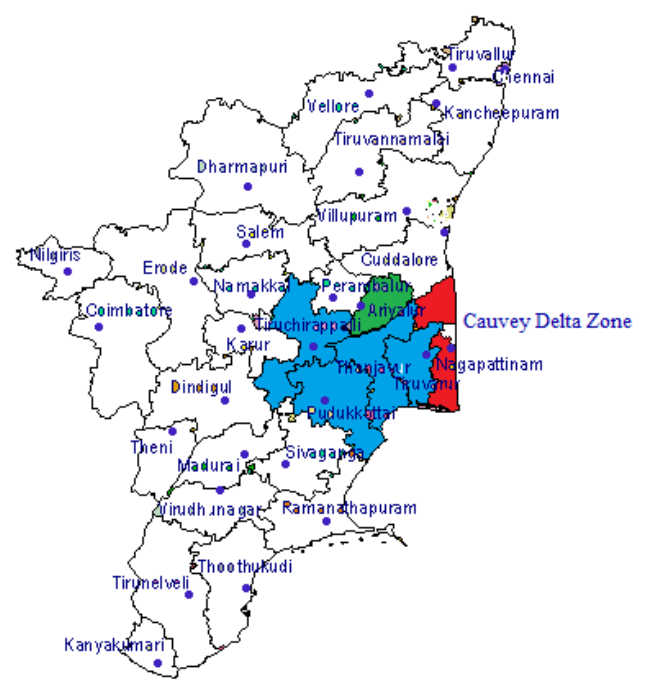

Figure 3. Spatial Pattern of Pulses 
Table 6 and 7. Classification of Productivity Indices of Cauvery Delta Zone

\begin{tabular}{|c|c|c|}
\hline \multicolumn{3}{|c|}{ Table 6. Cereal Crops } \\
\hline Index Range & Category & $\begin{array}{c}\text { Name of the } \\
\text { Districts }\end{array}$ \\
\hline Below 92.51 & $\begin{array}{c}\text { Low } \\
\text { Productivity } \\
\text { Regiuon }\end{array}$ & Nagapattinam \\
\hline $92.51-109.83$ & $\begin{array}{c}\text { Moderate } \\
\text { Productivity } \\
\text { Region }\end{array}$ & $\begin{array}{c}\text { Trichy, Pudukottai, } \\
\text { Thanjavur, } \\
\text { Thiruvarur }\end{array}$ \\
\hline Above 109.83 & $\begin{array}{c}\text { High } \\
\text { Productivity } \\
\text { Region }\end{array}$ & Ariyalur \\
\hline
\end{tabular}

\begin{tabular}{|c|c|c|}
\hline \multicolumn{3}{|c|}{ Table 7. Pulses Crops } \\
\hline Index Range & Category & $\begin{array}{c}\text { Name of the } \\
\text { Districts }\end{array}$ \\
\hline Below 85.67 & $\begin{array}{c}\text { Low } \\
\text { Productivity } \\
\text { Regiuon }\end{array}$ & Nagapattinam, \\
\hline $85.67-167.50$ & $\begin{array}{c}\text { Moderate } \\
\text { Productivity } \\
\text { Region }\end{array}$ & $\begin{array}{c}\text { Pudukottai, } \\
\text { Thanjavur, } \\
\text { Thiruvarur }\end{array}$ \\
\hline Above 167.50 & $\begin{array}{c}\text { High } \\
\text { Productivity } \\
\text { Region }\end{array}$ & Ariyalur \\
\hline
\end{tabular}

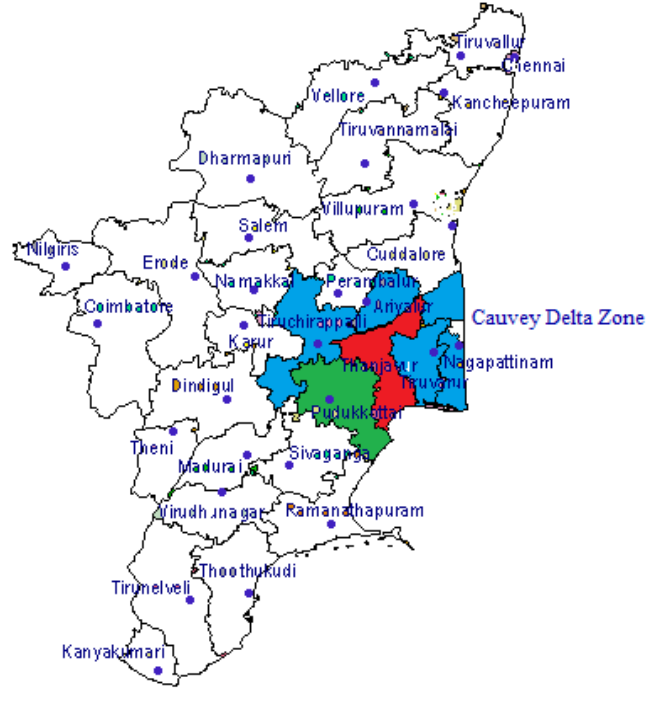

Figure 4. Spatial Pattern of Oil Seeds

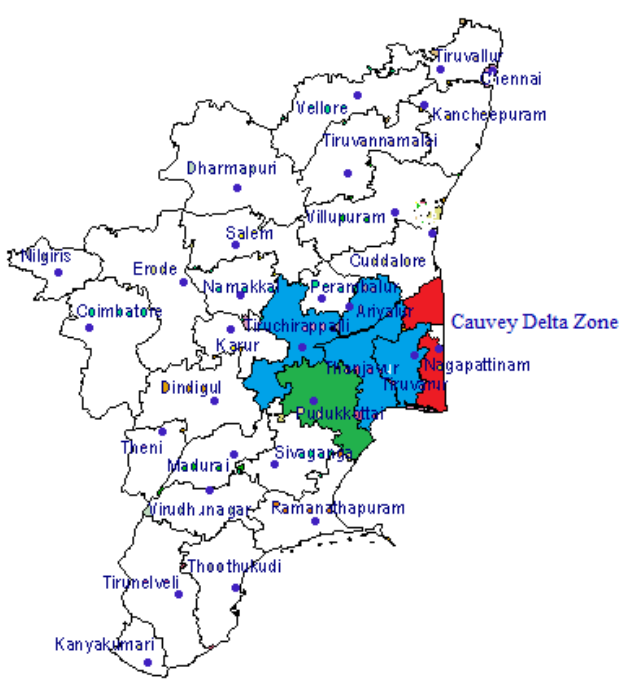

Figure 5. Spatial Pattern of Cash Crop

Table 8 and 9. Classification of Productivity Indices of Cauvery Delta Zone

\begin{tabular}{|c|c|c|}
\hline \multicolumn{3}{|c|}{ Table 8. Oil Seeds Crops } \\
\hline Index Range & Category & $\begin{array}{c}\text { Name of the } \\
\text { Districts }\end{array}$ \\
\hline Below 82.6 & $\begin{array}{c}\text { Low } \\
\text { Productivity } \\
\text { Regiuon }\end{array}$ & Thanjavur \\
\hline $82.36-179.30$ & $\begin{array}{c}\text { Moderate } \\
\text { Productivity } \\
\text { Region }\end{array}$ & $\begin{array}{c}\text { Nagapattinam, } \\
\text { Thiruvarur } \\
\text { Above } 179.30\end{array}$ \\
& $\begin{array}{c}\text { High } \\
\text { Productivity } \\
\text { Region }\end{array}$ & Ariyalur \\
\hline
\end{tabular}

\begin{tabular}{|c|c|c|}
\hline \multicolumn{3}{|c|}{ Table 9. Cash Crops } \\
\hline Index Range & Category & $\begin{array}{c}\text { Name of the } \\
\text { Districts }\end{array}$ \\
\hline Below 77 & $\begin{array}{c}\text { Low } \\
\text { Productivity } \\
\text { Regiuon }\end{array}$ & Nagapattinam, \\
\hline $77-110.83$ & $\begin{array}{c}\text { Moderate } \\
\text { Productivity } \\
\text { Region }\end{array}$ & $\begin{array}{c}\text { Thiruvarur, Trichy, } \\
\text { Ariyalur, Thanjavur }\end{array}$ \\
\hline Above 110.83 & $\begin{array}{c}\text { High } \\
\text { Productivity } \\
\text { Region }\end{array}$ & Pudukottai \\
& \multicolumn{2}{|c}{} \\
\hline
\end{tabular}

\section{Conclusion}

In this paper researcher identified spatial pattern of agriculture productivity of crops in the districts of Cauvery Delta zone in the year of 2011-2012. Among all the districts Ariyalur shows a HPR in Cereals, Pulses and Oilseeds, while Nagapattinam is in LPR in cereals, pulses and cash crops. In other district of Trichy and Thiruvarur districts shows MPR in all the categories. A slight variation in the spatial pattern was found in Thanjavur and Pudukottai. This classification depends on varieties in the soil type; local relief and shortage of rain fall are the important factors for the LPR of the crops in this zone. These variations are influenced by physical and socio economic factors. Soil fertility as determined by the constituents of a number of nutrients play a vital role in enhancing crop growth and yield per hectare. Among the socio-economic factors the size of land holdings is also responsible for decision making of farmers. Therefore it is needed that the productivity of crops per hectare be increased at least in MPR and LPR areas. Application of new agricultural technology 
brought with high yielding varieties which may suit to the agro climate zone will be of great help. Shortage of rainfall, Uncertainty dates of opening and closing of Mettur dam water for irrigation, undelayed monsoon, lack of adequate drainage facility in the delta region, the drainage cum irrigation net work in the delta could not drain the excess water in the monsoon season are the main reasons that affects the agricultural productivity in the zone.

\section{References}

[1]. Bhong A.B and Nimase A.G (2013), Levels of Agricultural Productivity in Solapur District (Maharashtra), Research Directions, Volume 1, issue 3. pp 1-6.

[2]. Sunil Ogale and virendra Nagarale (2014), Agricultural Productivity of Barmati Tashil, Pune District (Maharashtra), Journal of Agriculture and Veterinary Science, Volume 7; issue5 Ver II, pp 25-30

[3]. Shafi M (1984), Agricultural productivity and Regional imbalances, New Delhi, Concept Publishing Company.

[4]. Singh J., \& Dhillon, S.S, (2000), Agricultural Geography (2 $2^{\text {nd }}$ edition) New Delhi, Tata McGraw Hill.

[5]. Bhatia S.S (1967) Spatial Variation, Changes and Trends in Agriculture Efficiency in Uttar Pradesh, 1953-1963, Indian Journal of Agricultural Economics, Vol. 22,

[6]. Stamp L.D (1958), The measurement of Land Resources, the Geographical Review Vol.48 No.1 pp.110-116.

[7]. Shafi M (1960), Measurement of Agricultural efficiency in Uttar Pradesh, Economic Geography, Volume 36, No. 34 pp.296-305.

[8]. Jahan Mohan K.R et al. (2005), Growth Performance of Agriculture in Agro-Climatic Zones of Tamil Nadu, Agriculture Situation in India, Vol. LXI, pp. 679-686.

[9]. Lal Mervin Dharmasiri (2010), Measuring Agricultural Productivity using the Average Productivity Index, Srilanka Journal of Adanced Social Studies vol.1 - No.2.

[10]. Kalaivani M and A. Saravanadurai (2010), Growth Actions of Selected Cereal crops in Tamil Nadu state, International Journal of Applied Biology and Pharmaceutical Technology, Vol I; issue 3, pp 778-785.

[11]. Sakthi Mandal and Arijit Dhara (2012), Measurement of Agricultural productivity and levels of development in south 24 pargans district, West Bengal, International Journal of Agricultural Science and Research Vol.2 Issue 4 pp 91-98.

[12]. Muthumurugan et al. (2012), Composite Index Analysis of Inter-Regional Variations in Agricultural Development of Tamil Nadu, International Journal of Social Sciences and Inter Disciplinary Research Vol.1 No.4 pp 58-62.

[13]. Pager Mansaram Pandit (2012), Agricultural Development and Land Use Pattern in Nashik District of Maharastra, Mediterrronean Journal of Social Sciences, Vol.3 (16) pp. 151-161.

[14]. Rotaru AS et al. (2012), Usefulness of Principal Component Analysis in agriculture, Bulletin UASVM Horticulture 69(2) pp 504509 .

[15]. Safiquallah (2013), Impact of Regional disparities on Agricultural development in Uttar Pradesh - A Geographical Analysis, Global Journal of Human Social Science, Geography, Geo science, Environmental Management. Vol 2 issue 5 version1.0 pp 36-46.

[16]. Arulkumar C and Manimannan G (2014), Agriculture Productivity Performance of North- Western Zone in Tamilnadu Using Data Mining Techniques, Internationa Journal of Statistika and MAthematika, Volume 10, Issue 1, pp. 1-7.

[17]. Season and Crop Report 2011-2012, Department of Economics and Statistics, Chennai.

[18]. State of Indian Agriculture 2012-2013, Government of India, Ministry of Agriculture, Department of Agriculture and Cooperation, Directorate of Economics and Statistics, New Delhi.

[19]. Statistical Hand Book of Tamilnadu 2012-2013, Department of Economics and Statistics, Chennai.

\section{Author Profile}

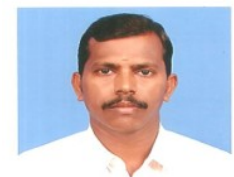

C. Arulkumar received his M.Sc.,M.Phil in Statistics from University of Madras, Chennai, India. He has eleven years of teaching experience at college level. He presented papers in conferences and published papers in International Journal. He has working knowledge in SPSS.

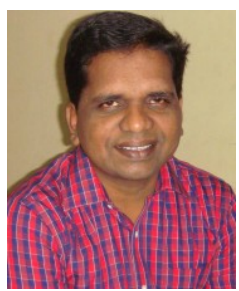

G. Manimannan received his M. Sc. M. Phil. Ph. D in Statistics from University of Madras, Chennai, India. He received PGDCA (Post Graduate Diploma in Computer Application) from Pondicherry University, Pondicherry, India. He has good research experience by working for many Project Guidance and consultation work in application of Statistics. He has published more than twenty nine research papers in various national and International journals. He is good in many programming languages like, FoxPro, HTML, COBOL, C, C++, VB, DBMS, SPSS, SYSSTAT, STATISTICA, MINITAB, MATLAB and working knowledge in SAS and R 